\title{
ANALISIS KEMAMPUAN LITERASI MATEMATIS SISWA KELAS VIII DENGAN SOAL PISA
}

\author{
Ratu Sarah Fauziah Iskandar ${ }^{1}$, Andri Nur Triyanto ${ }^{2}$, Laelasari ${ }^{3}$, Oki Setiawan $^{4}$ \\ ${ }^{1,2,3,4}$ Universitas Muhammadiyah Tangerang. \\ sarfauziah@gmail.com
}

\begin{abstract}
Abstrak
Penelitian ini bertujuan untuk menganalisis kemampuan literasi matematis siswa kelas VIII pada PISA untuk melihat kemampuan literasi matematis siswa kelas VIII.Penelitian ini dilaksanakan di SMPN 1 Curug.Subjek dalam penelitian ini adalah siswa kelas IX tahun ajaran 2020/2021. Dalam kondisi pandemik seperti sekarang ini, pembelajaran dilakukan daring sehingga peneliti menyebar soal penelitian pada 3 kelas yang berbeda dimana hasil yang terkumpul hanya 35 siswa dari 90 siswa. Dari 35 siswa yang diteliti, dipilih 6 siswa yang dikategorikan dalam kategori rendah, sedang, dan tinggi. Penelitian ini dikategorikan penelitian deskriptif dengan pendekatan kualitatif (deskriptif kualitatif).Instrumen yang digunakan adalah tes tertulis sebanyak 10 butir dan pedoman wawancara.Hasil penelitian menunjukkan literasi dari ke-6 subjek yang diteliti cukup baik, mereka cukup paham dengan soal yang telah diberikan. Namun, kendalanya yaitu ada beberapa siswa yang kesulitan dalam cara menjawab soal. Oleh karena itu kemampuan matematisnya masih tergolong rendah. Dari pertanyaan-pertanyaan yang diajukan oleh peneliti yang menanyakan mengenai soal termudah dan tersulit bagi siswa, hasilnya ada beberapa dari ke-6 subjek tersebut menjawab soal yang sama, karena dapat dipahami bahwasannya kemampuan siswa berbeda-beda dalam menyelesaikan masalah yang diberikan.
\end{abstract}

Kata Kunci : Literasi Matematis, Analisis Kemampuan Literasi Matematis, PISA.

\begin{abstract}
This study aims to analyze the mathematical literacy abilities of grade VIII students on PISA to see the mathematical literacy abilities of grade VIII students. This research was conducted at SMP 1 Curug. The subjects in this study were students of class IX in the 2020/2021 academic year. In a pandemic condition like today, learning is carried out boldly so that researchers spread research questions to 3 different classes where the results collected are only 35 students out of 90 students. Of the 35 students studied, 6 students were selected who were categorized into low, medium, and high categories. This research is categorized as a descriptive study with a qualitative approach (descriptive qualitative). The instrument used was a written test of 10 points and a new interview. The results showed that the literacy of the 6 subjects studied was quite good, they were quite familiar with the questions that had been given. However, the obstacle is that there are some students who have difficulty answering questions. Therefore, his mathematical ability is still low. From the questions posed by researchers who asked about the easiest and most difficult questions for students, the result was that some of the 6 subjects answered the same questions, because they could apply that students' abilities differed in solving the problems given.
\end{abstract}

Keywords: Mathematical Literacy, Mathematical Literacy Ability Analysis, PISA.

\section{PENDAHULUAN}

Permendiknas Nomor 22 Tahun 2006 dalam Sosialisasi KTSP Depdiknas (2009) [1]menjelaskan bahwa mata pelajaran matematika perlu diberikan kepada semua peserta 
didik mulai dari sekolah dasar untuk membekali peserta didik dengan kemampuan berpikir logis, analitis, sistematis, kritis, dan kreatif serta kemampuan bekerjasama serta mengembangkan kemampuan menggunakan matematika dalam pemecahan masalah dan mengkomunikasikan ide atau gagasan dengan menggunakan symbol, tabel, diagram, dan media lain. Pengajar, materi ajar dan metode pembelajaran menjadi faktor penting dan menjadi faktor penentu kualitas pembelajaran.Metode ajar sangat mempengaruhi kurikulum yang berlaku.Di kurikulum 2013 tidak hanya dibutuhkan penerapan konsep saja, tetapi lebih kepada bagaimana konsep itu dapat diterapkan dalam berbagai macam situasi, dan kemampuan siswa dalam bernalar dan berargumentasi tentang bagaimana soal itu dapat diselesaikan.

Menurut Shiel (2007)[2] Melalui Program for International Student Assessment (PISA) kemampuan nalar siswa dapat diamati. PISA merupakan singkatan dari Programme Internationale for Student Assessment yang merupakan suatu bentuk evaluasi kemampuan dan pengetahuan yang dirancang untuk siswa usia 15 tahun. Kemendikbud (2015) [3] tujuan PISA adalah untuk mengukur prestasi literasi membaca, matematika, dan sains siswa sekolah berusia 15 tahun di negara-negara peserta bagi Indonesia, manfaat yang dapat diperoleh antara lain adalah untuk mengetahui posisi prestasi literasi siswa Indonesia bila dibandingkan dengan prestasi literasi siswa di negara lain dan faktorfaktor yang mempengaruhinya. Oleh karena itu, hasil studi diharapkan dapat digunakan sebagai masukkan dalam perumusan kebijakan untuk peningkatan mutu pendidikan.Indonesia pertama kali mengikuti PISA pada tahun 2000.Indonesia berada di urutan ke-38 dari 41 negara yang terlibat dengan rata-rata 377.Pada hasil PISA mengenai literasi membaca, Indonesia mendapat peringkat ke-39 membaca skor 371. Pada tahun kedua diselenggarakannya PISA yaitu 2003 yang diikuti oleh 40 negara, literasi membaca Indonesia mendapat skor 382. Hal ini menunjukkan peningkatan literasi membaca kala itu.Tahun-tahun selanjutnya dilaksanakan pada tahun 2003, 2006, 2009, 2012, 2015, dan 2018.Jumlah negara yang turut serta pun semakin bertambah.Tahun 2018, negara yang mengikuti PISA ada 79 negara. Dari hasil tes, literasi membaca Indonesia mengalami puncak pada tahun 2009 yaitu dengan skor 402, namun tahun 2012 mengalami penurunan skor menjadi 396 dan tahun 2015 mengalami kenaikan 1 skor menjadi 397. Indonesia pada tahun 2015 masih berada pada 10 besar di peringkat terbawah yaitu 62 dari 72 negara dengan rata-rata 395. Hal yang menarik adalah dari ketiga aspek literasi yaitu membaca, kemampuan matematika, dan kemampuan sains meningkat dari tahun sebelumnya yaitu tahun 2012. Namun, pada tahun 2018 kini hasil survei menunjukkan Indonesia mengalami penurunan yaitu menempati posisi ke-74, alias peringkat ke enam dari bawah dengan skor 371 .

Hasil studi PISA 2018 dalam kategori Sains, Indonesia memperoleh skor 396, jauh di bawah rata-rata skor OECD sebesar 489. Sedangkan dalam Matematika, Indonesia ada di peringkat ke-7 dari bawah dengan skor 379 (rata-rata OECD 489).Sementara skor terendah yang diperoleh Indonesia ada pada kategori Membaca, yaitu sebesar 371 (ratarata OECD 489).Dalam periode survei ini, Indonesia masih kalah jauh dengan China dan Singapura yang secara berurutan berada di peringkat dua teratas.

Siswa yang berasal dari Indonesia dalam PISA belum ada yang mencapai level tertinggi yaitu level 6. Siswa yang berasal dari Indonesia dalam PISA yang tidak mencapai level 2 sebanyak 76\%, level minimal keluar dari kategori low achievers dan jumlah siswa yang mencapai level tertinggi 5 hanya 0,3\% (Baswedan, 2014) [4]. Hasil PISA yang rendah disebabkan oleh banyak faktor.Menurut Purnomo dan Dafik salah satu 
faktor penyebabnya adalah siswa Indonesia pada umumnya kurang terlatih dalam menyelesaikan soal-soal dengan karakteristik seperti soal-soal PISA.Hal ini dapat dilihat dari soal-soal yang diberikan guru di kelas, umumnya guru menyajikan soal rutin dan jarang dikaitkan dengan konteks kehidupan sehari-hari.Padahal, fokus dari PISA adalah literasi yang menekankan pada keterampilan dan kompetensi siswa yang diperoleh dari sekolah dan dapat digunakan dalam kehidupan sehari-hari (Johar, 2012) [5].Rendahnya nilai PISA menjadi tugas bagi Indonesia untuk mencari solusi memperbaiki nilainya. Solusinya dengan memberikan soal PISA atau soal yang memiliki karakteristik yang sama dengan PISA. Pemberian soal akan melatih siswa dan siswa terbiasa dalam mengerjakan soal-soal PISA.

Disisi lain, Pemerintah tetap berkomitmen untuk mengatasi kelemahan yang menjadi temuan PISA. Maka, salah satu rekomendasi yang diberikan adalah pengoptimalan teknologi informasi dan komunikasi (TIK) perlu dimanfaatkan untuk pembelajaran yang lebih efektif. Kemudian, untuk meningkatkan literasi, diminta agar sekolah lebih melibatkan siswa dalam membaca, memastikan rangkuman siswa benar-benar disampaikan dengan kata-kata sendiri tidak sekedar menyalin isi bacaan, memperkaya jenis bacaan, serta mendorong siswa untuk melakukan aktivitas membaca sebagai hiburan di waktu luang.

Beberapa temuan yang bisa ditindaklanjuti oleh guru dan orang tua untuk meningkatkan kemampuan membaca salah satunya adalah siswa yang dilibatkan oleh guru dalam pelajaran membaca memiliki skor membaca 30 poin lebih tinggi dibandingkan dengan siswa yang tidak pernah atau jarang terlibat.Selain itu, hal yang perlu dilakukan untuk meningkatkan kemampuan membaca siswa diantaranya adalah membiasakan siswa dengan jenis dan format bacaan yang beragam.Kemudian melatih siswa untuk berkonsentrasi pada isi bacaan, menandai atau merangkum dengan kata-kata juga sendiri terbukti efektif untuk memahami isi bacaan..

\section{METODE}

Penelitian ini dikategorikan penelitian deskriptif dengan pendekatan kualitatif (deskriptif kualitatif).Penelitian kualitatif adalah penelitian yang dapat menjelaskan dan menganalisis fenomena, peristiwa, aktivitas sosial, sikap kepercayaan, persepsi orang atau kelompok (Hamdi, 2014:9) [6].Sesuai dengan rumusan masalah yang telah dipaparkan, penelitian ini bertujuan mendeskripsikan kemampuan literasi matematika siswa menggunakan soal PISA. Pada laporan penelitian ini, literasi matematika siswa akan dideskripsikan secara rinci.

Data dalam penelitian berupa data hasil observasi, data hasil tes siswa dan juga wawancara kepada siswa selaku subjek penelitian.Siswa dapat menyelesaikan soal yang digunakan penelitian untuk memperjelas kemampuan literasi matematika dalam pemecahan masalah yang dicapai oleh siswa.Data penelitian ini berupa tingkat kemampuan literasi yang mengacu pada Sri Wardani (Sri Wardani dan Rumiati, 2011:11) [7].Sedangkan sumber data dalam penelitian ini adalah soal yang dibuat oleh peneliti yang telah divalidasi oleh ahli.Soal yang dibuat memuat indikator kemampuan literasi dan indikator pemecahan masalah matematika.Teknik pengumpulan data pada penelitian ini yaitu : 1) Teknik tes untuk mengukur kemampuan siswa dilihat dengan hasil tes siswa 2) Teknik 
dokumentasi digunakan untuk mendapatkan data yang dibutuhkan selama penelitian 3) Teknik wawancara digunakan untuk memperoleh data yang lebih akurat mengenai kemampuan literasi matematika dalam menyelesaikan masalah.

Subjek dalam penelitian ini adalah siswa dari kelas 9.4, 9.5, 9.6 yang dipilih secara acak yang berjumlah 35 siswa dari 90 siswa.Penelitian ini dilaksanakan pada semester ganjil tahun ajaran 2020/2021.Teknik pengumpulan data yang digunakan Tes Literasi Matematika (TLM) dan Pedoman Wawancara. Tes tulis yang diberikan berupa soal essay yang terdiri dari 10 soal PISA yaitu level 1,2,3,4 yang telah diterjemahkan kedalam bahasa Indonesia, dengan setiap butir soal merupakan perwakilan dari setiap level PISA. Tes tulis dilakukan agar peneliti memperoleh data tertulis tentang kemampuan literasi matematika siswa.Hasil jawaban siswa selanjutnya dinilai berdasarkan skor pada pedoman penskoran, kemudian dipilih satu jawaban yang sesuai dengan skor dan dianalisis dengan indikator kemampuan literasi matematika dan indikator pemecahan masalah.Adapun wawancara pada penelitian ini menggunakan metode wawancara semi terstruktur.Peneliti membawa sederetan pertanyaan, namun jika ketika wawancara terdapat hal yang tidak lazim atau hal yang perlu diungkap lebih dalam, peneliti dapat mengajukan pertanyaan - pertanyaan baru yang tidak terdapat pada pedoman.

Setelah data diperoleh melalui tes tulis dan wawancara, dilakukan analisis data dengan tahap - tahap sebagaimana yang dinyatakan oleh Miles dan Huberman (1984) dalam Sugiyono (2010 : 337) [8], yaitu : 1) Reduksi data dalam penelitian ini adalah suatu bentuk analisis yang memuat proses menggolongkan, membuang yang tidak perlu, dan mengorganisasikan data mentah yang diperoleh dari lapangan. Reduksi data dilakukan pada data hasil tes tulis yang dikerjakan siswa serta rekaman wawancara siswa. 2) Penyajian Data, pada tahap ini, data yang telah direduksi akan disajikan secara tertulis, secara terorganisasi dan terkategorisasi yang memungkinkan penarikan suatu kesimpulan, sehingga mempermudah untuk menarik kesimpulan. 3) Penarikan Kesimpulan, pada tahap ini, peneliti memberi makna dan penjelasan berdasarkan data yang telah disajikan. Penarikan kesimpulan ditujukan untuk mengungkap kemampuan literasi matematika siswa menggunakan soal PISA.

Untuk menguji keabsahan data, penelitian ini menggunakan triangulasi waktu, yaitu dengan pengecekan derajat kepercayaan beberapa sumber data yang diperoleh pada waktu yang berbeda (Sugiono,2009:127) [9]. Secara garis besar prosedur penelitian yang digunakan oleh peneliti terdiri atas empat tahap, yaitu : 1)Tahap Pendahuluan yaitu peneliti membuat proposal penelitian, 2)Tahap Perencanaan, yaitu peneliti merancang instrumen penelitian, 3)Tahap Pelaksanaan, yaitu peneliti menentukan subjek penelitian, memberikan Tes Literasi Matematika yang merupakan soal PISA dan mewawancarai siswa. 4)Tahap Analisis Data, yaitu menganalisis hasil tes tulis dan hasil wawancara siswa kemudian mendeskripsikan hasil analisis data. 


\section{HASIL DAN PEMBAHASAN}

Penelitian dilaksanakan di SMP Negeri 1 Curug Kabupaten Tangerang, pada kelas IX semester ganjil tahun pelajaran 2020/2021. Subjek dalam penelitian ini adalah siswa kelas IX.Peneliti mengujikan kepada 3 kelas yang terdiri dari 30 siswa.Dalam kondisi pandemic seperti sekarang ini, pembelajaran dilakukan daring sehingga peneliti menyebar soal penelitian pada 3 kelas, dimana hasil yang terkumpul hanya 35 siswa. Selanjutnya, 6 orang siswa dari 2 nilai tertinggi, 2 nilai sedang, dan 2 terendah akan diwawancarai mengenai kesulitan siswa dalam menjawab soal-soal PISA. Wawancara dilakukan melalui video call dan hasil wawancara direkam dengan perangkat lain seperti laptop atau handphone lain.

Dari data nilai siswa diperoleh rata-ratanya 52,56 dan standar deviasi nya 19,43. Nilai standar deviasi ini untuk mengetahui suatu ukuran penyimpangan suatu data.Selanjutnya, nilai siswa dikelompokkan kedalam 3 kategori yaitu tinggi, sedang, dan rendah.Didapatkan 7 siswa dengan kemampuan pemecahan masalah tinggi, 24 siswa dengan kemampuan sedang dan 4 siswa dengan kemampuan rendah.Selanjutnya dipilih masing-masing 2 orang dari setiap kategori tersebut untuk dijadikan subjek penelitian.

PISA mendefinisikan literasi matematika sebagai: formulasi, penggunaan dan interpretasi matematika dalam berbagai konteks (OECD, 2017) [10]. Termasuk penalaran matematika dan penggunaan konsep matematika, fakta dan alat untuk mendeskripsikan, menjelaskan dan memprediksi suatu kejadian. PISA juga menetapkan sebuah tingkat dasar kemampuan, pada skala dengan 6 sebagai level tinggi dan 1 sebagai level rendah. Tingkatan kemampuan tersebut yaitu :

TABEL 1 Tingkat Kemampuan dalam PISA

\begin{tabular}{|c|l|}
\hline Level & \multicolumn{1}{|c|}{ Deskripsi } \\
\hline 6 & $\begin{array}{l}\text { Siswa menggunakan penalarannya dalam menyelesaikan masalah } \\
\text { matematis, dapat membuat generalisasi, merumuskan serta } \\
\text { mengkomunikasikan hasil temuannya }\end{array}$ \\
\hline 5 & $\begin{array}{l}\text { Siswa dapat bekerja dengan model untuk situasi yang kompleks } \\
\text { serta dapat menyelesaikan masalah yang rumit }\end{array}$ \\
\hline 4 & $\begin{array}{l}\text { Siswa dapat bekerja secara efektif dengan model dan dapat memilih } \\
\text { serta mengintegrasikan representasi yang berbeda, kemudian } \\
\text { menghubungkannya dengan dunia nyata }\end{array}$ \\
\hline 3 & $\begin{array}{l}\text { Siswa dapat melaksanakan prosedur dengan baik dalam } \\
\text { menyelesaikan soal serta dapat memilih strategi pemecahan masalah }\end{array}$ \\
\hline 2 & $\begin{array}{l}\text { Siswa dapat menginterpretasikan masalah dan menyelesaikannya } \\
\text { dengan rumus }\end{array}$ \\
\hline 1 & $\begin{array}{l}\text { Siswa dapat menggunakan pengetahuannya untuk menyelesaikan } \\
\text { soal rutin, dan dapat menyelesaikan masalah yang konteksnya }\end{array}$ \\
\hline
\end{tabular}


umum

Level kemampuan matematika di atas merujuk pada Johar (2012) [11] yang akan digunakan peneliti sebagai rujukan penelitian. Menurut Setiawan (2014:247) [12] soal literasi matematika level 1 dan 2 termasuk kelompok soal dengan skala bawah, kemudian soal literasi matematika level 3 dan 4 termasuk soal dengan skala menengah, dan soal literasi matematika level 5 dan 6 termasuk kelompok soal dengan skala tinggi dengan konteks yang sama sekali tidak terduga oleh siswa. Sehingga, dapat disimpulkan, pada penelitian ini digunakan 2 instrumen penelitian yaitu berupa soal tertulis yang berjumlah 10 soal dan wawancara. Tujuan dari wawancara ini yaitu untuk mengetahui kemampuan literasi matematis siswa dalam proses pengerjaan soal-soal yang diberikan. Setelah diketahui paparan wawancara bersama ke 6 subjek diatas, dapat disimpulkan bahwasannya literasi dari ke-6 subjek ini cukup bagus, hampir semua soal mereka mampu menjelaskannya dan mereka cukup paham dengan soal yang telah diberikan. Namun, kesulitan mereka yaitu salah satunya bingung cara menjawab soal. Jadi, kemampuan matematisnya masih tergolong rendah.

Dari pertanyaan-pertanyaan yang diajukan oleh pewawancara diantaranya yaitu soal termudah dan tersulit bagi siswa dan tidak banyak dari ke-6 subjek ini menjawab soal yang sama, karena dapat dipahami bahwasannya kemampuan siswa berbeda-beda dalam menyelesaikan masalah yang diberikan.

\section{KESIMPULAN}

Berdasarkan hasil penelitian dan pembahasan diperoleh kesimpulan bahwa kemampuan matematika terdiri dari 6 indikator yaitu:1)Siswa dapat menggunakan pengetahuannya untuk menyelesaikan soal rutin, dan dapat menyelesaikan masalah yang konteksnya umum; 2)Siswa dapat menginterpretasikan masalah dan menyelesaikannya dengan rumus; 3)Siswa dapat melaksanakan prosedur dengan baik dalam menyelesaikan soal serta dapat memilih strategi pemecahan masalah; 4)Siswa dapat bekerja secara efektif dengan model dan dapat memilih serta mengintegrasikan representasi yang berbeda, kemudian menghubungkannya dengan dunia nyata; 5)Siswa dapat bekerja dengan model untuk situasi yang kompleks serta dapat menyelesaikan masalah yang rumit; 6)Siswa menggunakan penalarannya dalam menyelesaikan masalah matematis, dapat membuat generalisasi, merumuskan serta mengkomunikasikan hasil temuannya.

Kemampuan literasi matematis ditinjau dari kemampuan matematika siswa dapat disimpulkan bahwa level yang dapat dicapai setiap siswa berbeda-beda. Siswa dengan kemampuan matematika tinggi dapat memahami soal dengan baik. Siswa tersebut mampu menyelesaikan 9 dari 10 soal yang diberikan, dimana didalamnya memuat level 1 sampai dengan level 4 yang ada dalam PISA. Siswa dengan kemampuan tinggi lainnya juga dapat menyelesaikan level 1 sampai dengan level 4. Perbedaannya adalah dari 10 soal yang diberikan hanya 8 diantaranya di jawabnya dengan benar. Siswa dengan kemampuan matematika sedang mampu menjawab 5 soal benar dimana pada soal tersebut memuat level 2,3,4. Siswa dengan kemampuan sedang lainnya mampu menyelesaikan level 1,2, 4 dan menjawab 4 soal dengan benar .Untuk Siswa dengan kemampuan rendah hanya mampu menjawab 2 soal dengan benar dan siswa kemampuan rendah lainnya juga hanya mampu menjawab 1 soal dengan benar.

Dari hasil tersebut menjadikan penelitian dasar untuk peneliti lain mengenai penelitian selanjutnya. Berdasarkan hasil di atas penelitian memberikan saran sebagai berikut: 
(1)Guru harus lebih sering memberikan soal yang berbentuk PISA karena dalam soal PISA tersebut dapat meningkatkan kemampuan analisis literasi matematis siswa. (2)Diharapkan adanya olimpiade soal PISA untuk terus meningkatkan prestasi level PISA di Indonesia. (3)Penelitian lanjutan mengenai pencapaian dan peningkatan analisis literasi matematis siswa.

\section{DAFTAR RUJUKAN}

[1] Permendiknas Nomor 22 Tahun 2006 dalam Sosialisasi KTSP Depdiknas. (2009). (Dalam Jatri, Fauzan. 2013. "Penerapan Problem Posing Dalam Pembelajaran Matematika Untuk Meningkatkan Kemampuan Pemecahan Masalah dan Berpikir Logis Matematis Siswa”. (Online). (http://repository.upi.edu/id/eprint/8526). Diakses 3 Februari 2020)

[2] Shiel. (2007). (Dalam Khafifah, Anisa. 2019. "Pelevelan Kemampuan Literasi Matematika Siswa Berdasarkan Kemampuan Matematika Dalam Menyelesaikan Soal PISA Konten Change and Relationship. (Hal 1).Digital Repository Universitas Jember.(Skripsi Online). (https://repository.unej.ac.id/handle/123456789/92747). Diakses 3 Februari 2020).

[3] Kemendikbud. (2015). (Dalam Rahmawati, Eka, dkk. 2016. Analisis Kemampuan Matematis Siswa SMP Dalam Menyelesaikan Soal Matematika bertipe PISA. (Hal 1).Jurnal Ilmiah Mahasiswa FKIP Prodi Matematika, (Online), (https://e-journal.upp.ac.id). Diakses 14 November 2020.

[4] Baswedan. (2014) (Dalam Mansur, Nabilah. 2018. "Melatih Literasi Matematika Siswa dengan Soal PISA". (Hal 142).PRISMA, PROSIDING SEMINAR NASIONAL MATEMATIKA.(Online). (https://journal.unnes.ac.id/sju/index.php/prisma). Diakses 3 Februari 2020).

[5] Johar. (2012) (Dalam Mansur, Nabilah. 2018. "Melatih Literasi Matematika Siswa dengan Soal PISA". (Hal 140).PRISMA, PROSIDING SEMINAR NASIONAL MATEMATIKA.(Online). (https://journal.unnes.ac.id/sju/index.php/prisma). Diakses 22 September 2020).

[6] Hamdi. (2014:19). (Dalam Saputro, Roynaldy. 2018. “Analisis Kemampuan Literasi Matematika Siswa Dalam Menyelesaikan Soal Tipe PISA 2015. (Hal 3).(Skripsi Online). (http://eprints.ums.ac.id/67590/12/01\%20Naskah\%20Publikasi.pdf). Diakses 19 Maret 2020).

[7] Sri Wardani dan Rumiati.(2011:11). (Dalam Saputro, Roynaldy. 2018. "Analisis Kemampuan Literasi Matematika Siswa Dalam Menyelesaikan Soal Tipe PISA 2015. (Hal 3-4). (Skripsi Online). (http://eprints.ums.ac.id/67590/12/01\%20Naskah\%20Publikasi.pdf).Diakses 19 Maret 2020).

[8] Sugiyono. (2010:377). (Dalam Sulfiah, S.K, dkk. 2018. “Analisis Literasi Matematika Siswa Berkemampuan Matematika Tinggi Pada Soal PISA”. (Hal 52).Jurnal Pi, Pendidikan Matematika dan Integrasinya (Vol. 2), pp. 48-55. (Online). (http://ejournal.hikmahuniversity.ac.id/index.php/math/article/view/58). Diakses 19 Maret 2020).

[9] Sugiyono. (2009:127). (Dalam Sulfiah, S.K, dkk. 2018. "Analisis Literasi Matematika Siswa Berkemampuan Matematika Tinggi Pada Soal PISA”. (Hal 52).Jurnal Pi, Pendidikan Matematika dan Integrasinya (Vol. 2), pp. 48-55. (Online). (http://ejournal.hikmahuniversity.ac.id/index.php/math/article/view/58). Diakses 19 Maret 2020).

[10] OECD. (2017). (Dalam Dinni, H.N. 2018."HOTS (High Order Thinking Skills) dan Kaitannya dengan Kemampuan Literasi Matematika.(Hal 173).PRISMA, PROSIDING SEMINAR NASIONAL MATEMATIKA.(Online). (https://journal.unnes.ac.id/sju/index.php/prisma). Diakses 22 September 2020).

[11] Johar. (2012). (Dalam Dinni, H.N. 2018."HOTS (High Order Thinking Skills) dan Kaitannya dengan Kemampuan Literasi Matematika.(Hal 170).PRISMA, PROSIDING SEMINAR NASIONAL MATEMATIKA.(Online). (https://journal.unnes.ac.id/sju/index.php/prisma). Diakses 22 September 2020).

[12] Setiawan. (2014:247). (Dalam Dinni, H.N. 2018."HOTS (High Order Thinking Skills) dan Kaitannya dengan Kemampuan Literasi Matematika.(Hal 174).PRISMA, PROSIDING 
Jurnal Gammath, Volume 6 Nomor 1, Maret 2021

SEMINAR

NASIONAL

MATEMATIKA.(Online).

(https://journal.unnes.ac.id/sju/index.php/prisma). Diakses 22 September 2020). 